\title{
Rancang Aplikasi Chatbot Sebagai Virtual Asisten Dalam Pelayanan Pengguna Data Di Badan Pusat Statistik Provinsi Maluku
}

\author{
Adela Santhy Toamain, \\ Badan Pusat Statistik Provinsi Maluku \\ adelas@bps.go.id
}

\begin{abstract}
Abstrak
Pelayanan dalam suatu instansi sangat menentukan tingkat kepuasan dari pengguna. Pelayanan yang baik perlu ditunjang dengan sarana yang optinal dan memadai salah satunya adanya sentuhan teknologi informasi. Badan Pusat Statistik sebagai instansi penyedia data tentunya perlu memanfaatkan teknologi untuk layanan permintaan data. Teknologi yang dipakai BPS Provinsi Maluku untuk melayani kebutuhan pengguna data melalui web, email, maupun chat langsung dengan petugas melalui sosial media. Teknologi yang diterapkan selama ini masih kurang cepat dana tepat dalam memenuhi kebutuhan pengguna data seperti email dikarenakan petugas tidak rutin membuka email sehingga dalam melayani permintaan data kurang responsif, selain itu pengguna data yang tidak paham cara mencari data di website BPS daerah. Pengguna data yang melakukan permintaan data lewat chat juga tidak langsung di respons. Pada penelitian ini dirancang sebuah sistem yang dapat menjawab kebutuhan pengguna data secara tepat dan tepat yaitu dengan merancang sebuat chatbot dengan menggunakan telegram sebagai Virtual Assistant. Hasil rancangan didapat bahwa sistem yang dibuat dapat menggantikan proses yang berjalan selama ini, sehingga dapat mempercepat proses pelayanan pengguna data, lebih interaktif dan tepat sasaran.
\end{abstract}

Kata kunci: Penjawab otomatis, bot, data, telegram

\begin{abstract}
Services in an agency determine the level of satisfaction of the user. Good service needs to be supported by optimal and adequate facilities, one of which is the touch of information technology. The Central Bureau of Statistics as a data provider agency certainly needs to utilize technology for data request services. The technology used by the Maluku Provincial BPS to serve the needs of data users via the web, email, and direct chat with officers via social media. The technology applied so far is still not fast enough to meet the needs of data users such as email because officers do not regularly open emails so that in serving data requests it is less responsive, besides data users who do not understand how to find data on the regional BPS website. Data users who make data requests via chat are also not immediately responded to. In this study, a system was designed to answer the needs of data users precisely and precisely by designing a chatbot using telegram as a Virtual Assistant. The results of the design show that the system created can replace the process that has been running so far so that it can speed up the data user service process, be more interactive and on target.
\end{abstract}

Keywords: Auto attendant, bot, data, telegram 


\section{PENDAHULUAN}

Era Globalisasi saat ini menyebabkan perkembangan teknologi informasi yang semakin pesat dan tidak dapat dihindari [1]. Perkembangan teknologi informasi dimulai dari adanya kemajuan dan perkembangan dibidang komputerisasi. Dengan berkembangnya teknologi akan semakin memudahkan proses komunikasi. Persoalan jarak, ruang dan waktu, bukan menjadi kendala untuk memperoleh informasi dengan lebih cepat [2]. Kemajuan teknologi mengakibatkan proses interaksi manusia di belahan dunia dapat dijangkau. Kemajuan teknologi dengan pemanfaatan internet menjadikan semua keperluan manusia dapat terpenuhi, misalnya dengan penggunaan whattsapp, facebook messenger, line, telegram, dll dapat memudahkan akses manusia untuk memenuhi segala kebutuhan dalam berkomunikasi dengan cepat [3]. Sebagai contoh dengan FB atau melalui zoom saat ini interaksi fisik seperti pertemuan, kebiasaan silahturahmi, rapat, yang dilakukan biasanya dengan kontak fisik manusia semakin berkurang. Begitu pula layanan penggunan pesan singkat yang dahulu marak digunakan yaitu Short Masaage Service (SMS) mulai tergeser dengan penggunaan sarana aplikasi IM (Instant Massanger). Jumlah pengguna aplikasi Instant Messenger ini berkembang dengan cepat karena berbagai penawaran fitur dengan kualitas yang berbeda. Aplikasi Whattapp adalah aplikasi IM yang banyak digunakan masyarakat dalam berkomunikasi pesan singkat. Namun dibalik itu whattapp masih memiliki beberapa kekurangan dibanding dengan telegram. Kelebihan penggunaan telegram diantaranya: gratis serta tidak adanya iklan yang menganggu, ringan, ukuran grafis dalam aplikasi sangat kecil sehingga dijalankan ringan, Dapat diakses secara bersama dari berbagai perangkat. Hal ini berbeda dengan whattapp yaitu jika menggunakan wa web, tentu harus digunakan secara online namun untuk telegram tidak perlu dilakukan secara online sehingga akan menghemat penggunaan batrei dan paket data, dapat mengirim berbagai jenis file meskipun dengan ukuran yang besar, maksimal pembagian file dapat mencapai 1,5 GB dibanding dengan WA yang hanya dibatasi $16 \mathrm{MB}$, selanjutnya grup telegram dapat mencapai 100 orang dan dapat 1000 orang jika di upgrate ke supergrup, terdapat fitur chanel pada telegram. Broadcasting dilakukan dengan menggunakan channel dan dapat menampung anggota hingga tak terbatas, memiliki fitur bot, yaitu akun yang dijalankan oleh aplikasi. Bot dilengkapi dengan Application programming Interface Official, serta memiliki keamanan yang baik dibanding dengan whatsapp. [4] Aplikasi telegram dipilih, karena merupakan aplikasi pengirim pesan yang cukup dikenal oleh pengguna. [5] Dengan adanya pemilihan aplikasi IM yang berkualitas akan membantu dalam komunikasi yang lebih cepat dan tepat.

Komunikasi yang cepat dan tepat sangat berperan dalam kegiatan pelayanan. Badan Pusat Statistik atau BPS merupakan salah satu Lembaga pemerintah non Kementrian yang bertanggungjawab langsung kepada Presiden. Sebagai salah satu instansi pemerintah yang mempunyai visi menjadi pelopor data statistik terpecaya untuk semua dengan dengan salah satu misi yaitu menyediakan data statistik berkualitas tentu menjadi suatu tantangan bagi lembaga ini untuk terus berinovasi dalam menyediakan produk-produk yang dapat digunakan dalam meningkatkan kualitas penyediaan data dan pelayanan.[6] Layanan pengguna merupakan ujung tombak terpenting dalam membangun kepuasan terhadap pengguna. [7] Untuk melayani pengguna data, BPS menyediakan aplikasi berbasis website yang dapat di kunjungi oleh setiap pengguna yang dapat mengakses internet. Meskipun demikian masih terdapat kelemahan seperti karena kurangnya pengetahuan pengguna, yang membuat kesulitan dalam pencarian data. Selain itu interaksi pengguna dengan petugas yang tidak optimal seperti permintaan data yang dilakukan melalui email dan penyampaian data kepada pengguna yang lambat dikarenakan keterlambatan petugas BPS dalam membuka email secara rutin, atau dalam interaksi tatap muka petugas yang membutuhkan effort dalam mencari tata letak data yang dibutuhkan pengguna. Oleh karena itu perlu adanya suatu layanan yang lebih optimal yang dapat mengakomodir layanan dengan cepat dan tepat 
sesuai dengan permintaan pengguna data sehingga dapat memberikan kepuasan kepaa pengguna. Melihat akan kelebihan telegram sebagai sarana IM dengan fitur yang cukup lengkap dan merupakan aplikasi yang telah menjamur di masyarakat, maka aplikasi ini dapat dikembangkan menjadi suatu sistem kecerdasan buatan dalam memberikan pelayanan yang baik terhadap pengguna.

\section{METODE}

\subsection{Metode Pengembangan Sistem}

Metode yang digunakan dalam penelitian adalah waterfall. Penggunaan metode waterfall karena merupakan salah satu model yang klasik namun bersifat sistematis, dan terurut dalam pembuatan software. [8] Model ini yang diperkenalkan oleh Winston Royce pada tahun 1970 termasuk dalam model generic pada rekayasa perangkat lunak, namun merupakan salah satu metode yang sering dipergunakan dalam pemuatan Software Engineering (SE). Disebut waterfell karena setiap tahapan harus dilalui dan tidak akan berpindah sebelum tahapan awal selesai dekerjakan. Setiap tahapan yang terjadi dalam penggunaan model ini selalu berurutan. [9]

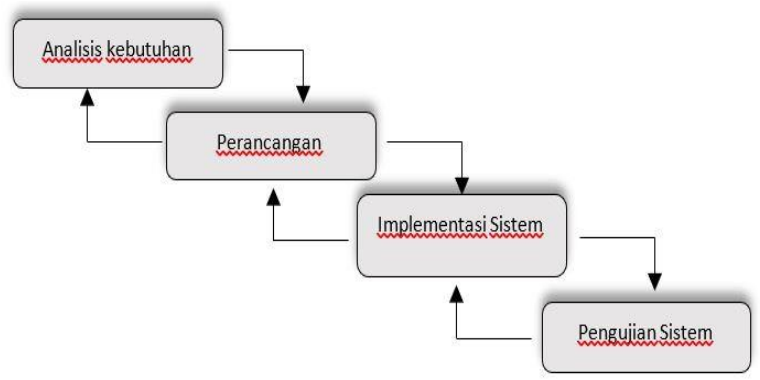

Gambar 1. Metode Waterfall

\subsection{Chatbot}

Aplikasi Chatbot pertama kali diciptakan pada tahun 1994 oleh Michel Mauldin untuk menjelasakan program percakapan. [10]. Chatbot adalah suatu program aplikasi kecerdasan buatan yang dirancang untuk dapat melakukan percakapan dengan pengguna melaui media teks. Banyak bots yang dapat digunakan dalam menginterprestasikan serta menanggapi pesan manusia, namun pada intinya bots hanya mampu untuk mengartikan kata kunci yang telah diinput serta membalas pesan yang diinput melalui kata kunci yang paling tepat atau menggunakan pola kata yang hampir mirip dari database yang telah dibuat dan tersimpan dalam server.

Telegram menyediakan fitur API (Appication Programming Interface) dengan adanya fitur bot. Fitur bot dalam telegram dimulai dengan melakukan pendaftaran terhadap akun bot yang digunakan sebagai chatbot. [11] Terdapat 2 komponan utama yang dalam aplikasi percakapan ini yaitu chat dan bot. Chat adalah pembicaraan atau percakapan dan bot adalah sebuah program yang terdiri dari sejumlah kata, dan dalam memberikan respon jawaban ketika diberikan input percakapan. Chat bot akan menjawab secara otomatis berdasarkan pola kata atau kata kunci yang telah diketik oleh pengguna.[12]

\subsection{Python}

Python adalah Bahasa pemograman yang dikembangkan untuk membuat source code sehingga dapat mudah dibaca. Pythin pertama kali dibuat pada awal tahun 1990 oleh Guido van Rossum sebagai pengganti basaha pemograman ABC. Saat ini Python banyak digunakan karena bersifat open source artinya tanpa lisensi sehingga dapat dikembangkan oleh siapa saja.

Pythin dikenal dikenal dan dieksekusi dengan sebuah interpreter dengan dua mode yaitu mode baris perintah dan modus script. Pada baris perintah diketiikan pada shell dan pyhton menampilkan hasil. Cara lainnya yaitu menyimpan perintah pyton dalam satu file sebagai script. Pyhon dapat diketik dengan menggunakan text editor seperti Notepad.[13]

\subsection{Heroku}

Heroku adalah cloud platform As a Service yang berfungsi sebagai web layanan dalam mengelola informasi dan knowleage base.[14]

\section{HASIL DAN PEMBAHASAN}

\subsection{Analisis Sistem Lama}

Proses permintaan data pada BPS Provinsi Maluku menggambarkan tentang mekanisme bagaimana layanan yang terjadi di BPS Provinsi yang dimulai dari kedatangan pengunjung, permintaan data sampai dengan selesainya proses permintaan data yang dilakukan melalui 
website. Gambar 2 menjelaskan tentang alur permintaan data pengunjung.

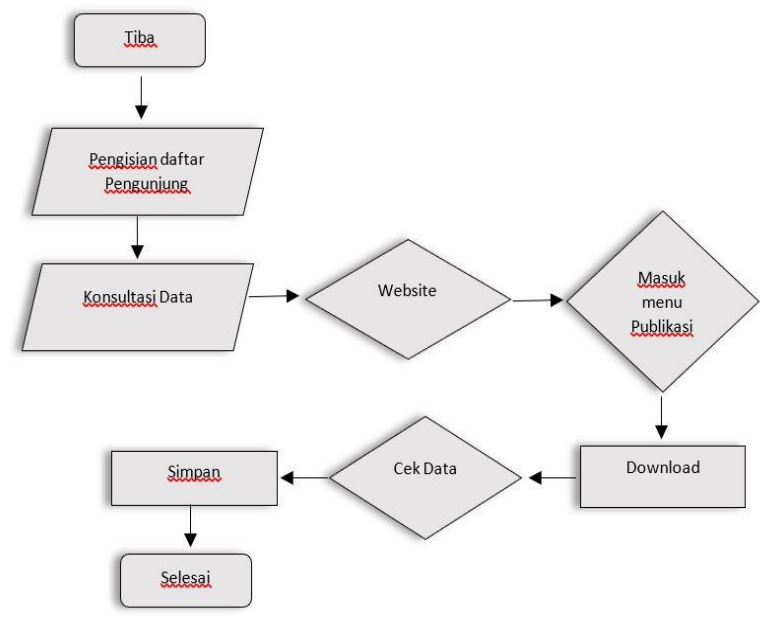

Gambar 2. Flowchart permintaan data dengan sistem lama

\subsection{Analisis dan Rancangan sistem baru}

BPS Provinsi Maluku merupakan salah satu lembaga instansi pemerintah yang menyediakan pelayanan permintaan data. Untuk menunjang proses layanan yang maksimal terhadap pengguna data maka perlu diciptakan akses layanan yang simpel sehingga pengguna layanan dapat dengan mudah menerima akses dengan baik. Sistem layanan yang dilakukan selama ini oleh BPS Provinsi Maluku selama ini mengikut penerapan BPS Pusat yaitu melalui website. Untuk menunjang layanan penyediaan data yang lebih optimal dan produktif, maka BPS Provinsi Maluku melakukan uji coba penerapan layanan permintaan data dengan sistem penjawab otomatis yang diintegrasikan melalui bot telegram. Pengunjung sebagai pengguna dapat berinteraksi dengan Bot telegram dengan cara mengirim pesan atau perintah melalui aplikasi telegram yang telah terinstal pada perangkat yang digunakan. Perintah atau pesan yang dikirimkan pada Bot akan secara otomatis diteruskan oleh Telegram server menuju bot server yang berfungsi sebagai webhook. Kemudian bot server akan mengirimkan tanggapan berupa balasan kepada pengguna sesuai dengan permintaan data yang dibutuhkan oleh pengunjung.

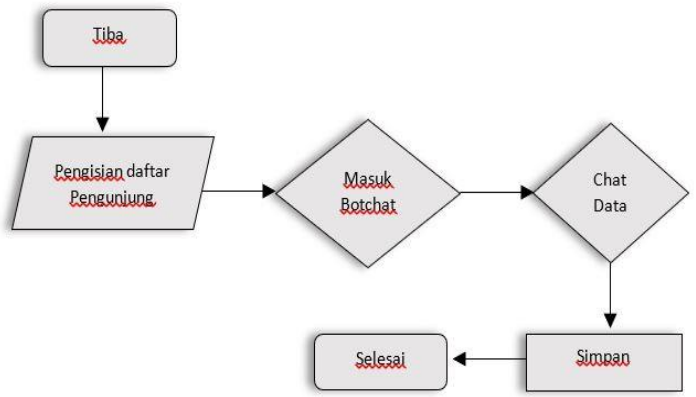

Gambar 3. Flowchart permintaan data dengan sistem baru

Adapun gambaran dari arsitektur bot telegram akan dibuat seperti gambar 4 .

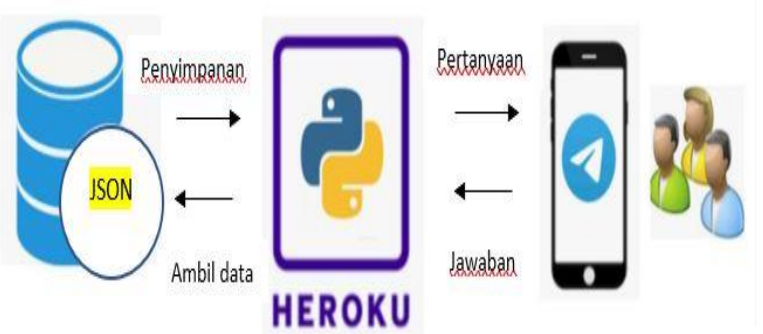

Gambar 4. Arsitektur Bot Telegram

Knowledge Bot Telegram dibuat dengan menggunakan Format JSON. Script Python di hosting dengan menggunakan platform Heroku. Heroku adalah sebuah cloud platform yang menjalankan bahasa pemrograman tertentu, Heroku mendukung bahasa pemrograman seperti Ruby, Node.js, Python, Java, PHP, dan lainlain. Setiap pertanyaan melalui telegram akan diproses oleh script python yang kemudian pola kalimat yang dihasilkan dari proses pengolahan kata akan dicocokkan di tempat penyimpanan knowledge yang berupa JSON. Setelah menemukan pola kalimat yang cocok maka Heroku akan memproses dengan mengambil jawaban dari database dan mengirim ke pengguna data. 


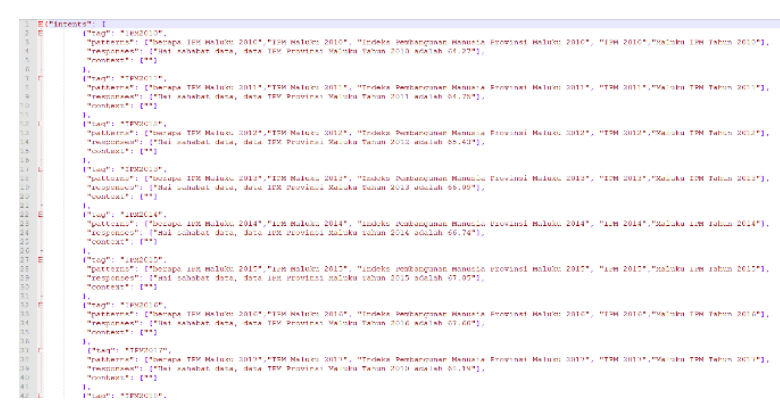

Gambar 5. Struktur format JSON

Knowledge yang dibuat dalam bentuk JSON diberi nama intents, dimana intents memiliki struktur tertentu seperti di gambar 5. Terdapat tag, patterns, response, dan context. Tag digunakan untuk memberikan label pada sebuah object. Patterns berisi kata-kata yang mungkin sering ditanyakan dalam permintaan data, kata-kata yang dituliskan pada pattern selanjutnya akan di training dengan menggunakan tensorflow sehingga setiap permintaan data yang masuk akan dicocokkan kemiripannya dengan pattern yang dibuat. Response adalah jawaban yang dihasilkan setelah proses pengolahan kata selesai dilakukan.

\subsection{Perancangan Sistem}

Untuk mendapatkan rancangan sistem yang baik, dibutuhkan sebuah rancangan yang terstruktur dan memadai. Rancangan sistem ini meliputi use case diagram, rancangan basis data, aktivitas diagram dan implementasi.

\subsubsection{Use Case Diagram}

Use case diagram merupakan pemodelan untuk kelakukan sistem informasi yang akan dikerjakan. Menurut Salahuddin (2013) Use case mendiskripsikan sebuah interaksi antara satu atau lebih actor dengan sistem informasi yang akan dibuat. Secara umum, use case digunakan untuk mengetahui fungsi yang dibutuhkan dalam sebuah sistem informasi dan peranan dari setiap fungsi dalam penggunakan sistem informasi. Adapun use case diagram untuk membangun rancang aplikasi ditunjukan dalam Gambar 6 dibawah ini.

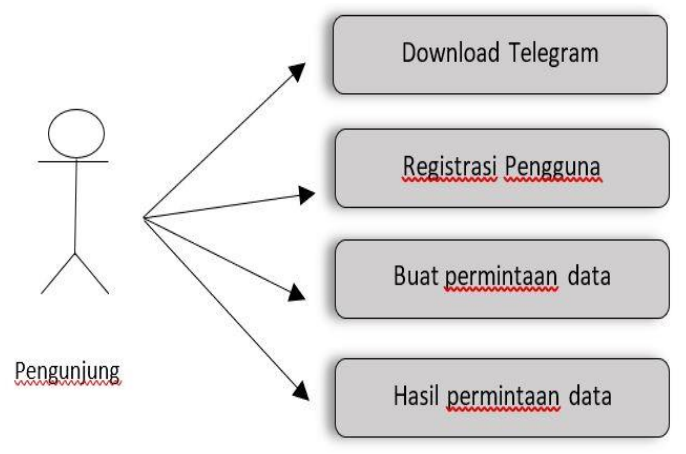

Gambar 6. Use Case diagram

Berdasarkan gambaran dapat dilihat bahwa actor yaitu pengguna utama bot telegram dalam hal ini adalah pengungung. Sedangkan untuk use case dapat dilihat pada table 1 dibawah ini

Tabel 1. Use case dan Deskripsi

\begin{tabular}{|l|l|}
\hline \multicolumn{1}{|c|}{ Use case } & \multicolumn{1}{|c|}{ Deskripsi } \\
\hline $\begin{array}{l}\text { Download } \\
\text { Telegram }\end{array}$ & $\begin{array}{l}\text { Setiap pengguna diwajibkan } \\
\text { untuk dapat menginstal } \\
\text { aplikasi telegram }\end{array}$ \\
\hline $\begin{array}{l}\text { Registrasi } \\
\text { Pengguna }\end{array}$ & $\begin{array}{l}\text { Dalam tahap ini setiap } \\
\text { pengguna melakukan registrasi } \\
\text { telebih dahulu sehingga data } \\
\text { pengguna dapat tersimpan } \\
\text { dalam server database. Proses } \\
\text { registrasi dilakukan dengan } \\
\text { menyebutkan nama pengguna, } \\
\text { Asal Instansi dan Tujuan } \\
\text { permintaan data }\end{array}$ \\
\hline $\begin{array}{l}\text { Buat } \\
\text { permintaan } \\
\text { data }\end{array}$ & $\begin{array}{l}\text { Dalam tahap ini pengguna } \\
\text { dapat mengakses jenis } \\
\text { permintaan data sesuai } \\
\text { dengan jenis kebutuhan data } \\
\text { yang yang diperlukan, misalnya } \\
\text { dengan mengetik: "saya } \\
\text { membutuhkan data ipm 2019" } \\
\text { atau dapat kalimat lain yang }\end{array}$ \\
\hline
\end{tabular}




\begin{tabular}{|l|l|}
\hline & $\begin{array}{l}\text { merujuk pada jenis permintaan } \\
\text { data yang dibutuhkan }\end{array}$ \\
\hline $\begin{array}{l}\text { Hasil } \\
\text { permintaan } \\
\text { data }\end{array}$ & $\begin{array}{l}\text { Tahap ini merupakan proses } \\
\text { penyajian data dan informasi } \\
\text { mengenai data yang } \\
\text { dibutuhkan oleh pengguna } \\
\text { data }\end{array}$ \\
\hline
\end{tabular}

\subsubsection{Rancangan knowledge}

Aplikasi bot telegram yang dibuat ini merupakan sistem aplikasi yang dibangun dengan menggunakan rancangan knowledge yang dinamakan intents terdiri atas object dan array json di dalam object. Array json terdiri atas tag, patterns, response dan context. Di dalam tag isian berupa string. Pattern berupa kumpulan katakata yang akan menjadi kandidat untuk dicocokkan dengan kalimat dari pengguna data melalui telegram. Pattern berupa array dikarenakan terdiri dari beberapa kata. Response adalah jawaban dari pertanyaan pengguna data. Response berupa array karena jawaban bisa dengan menggunakan berbagai pilihan kalimat. Didalam format json yang dibuat merupakan format dengan tipe array bersarang dikarenakan intents merupakan array dan di dalam intents terdapat array lainnya seperti di dalam patterns, response, dan context.

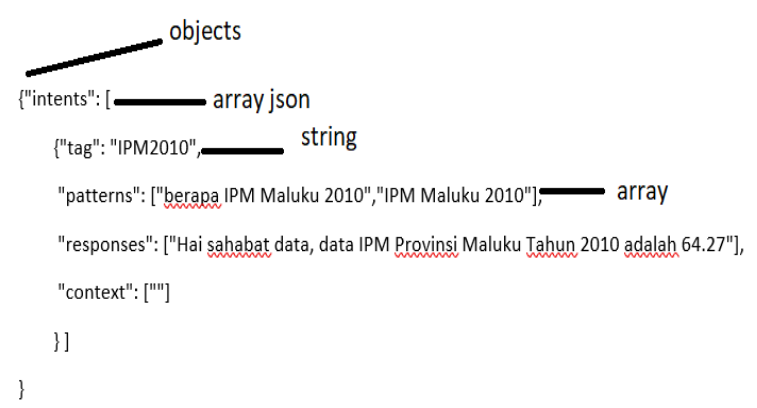

Gambar 7. Rancangan Knowledge

\subsection{Implementasi}

Langkah pertama dalam pembuatan bot telegram adalah melakukan proses bot baru yang akan dibantu dengan adanya API telethon. Setelah proses registrasi Bot berhasil, Bot akan melakukan request dalam berkomunikasi pada telegram server. Adapun proses registrasi yang dilakukan dapat dilihat pada gambar 8 di bawah ini.

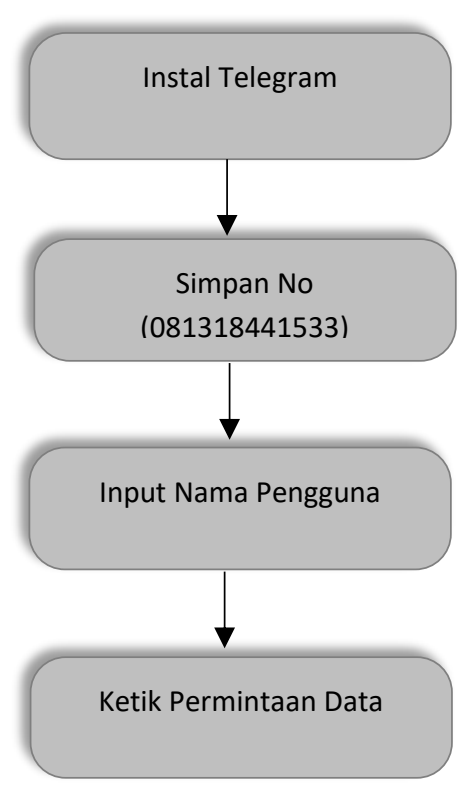

Gambar 8. Proses registrasi

Bot server pada aplikasi bot telegram dibangun dengan menggunakan Bahasa pemograman pyhon. Bot server digunakan sebagai webhook untuk dapat berkomunikasi dengan server telegram melalui protocol. Bagi pengguna data, Langkah yang dilakukan adalah menginstal aplikasi telegram. Setelah itu, Input Nama dan asal Instansi sebagai data penunjung. Proses registrasi hanya dilakukan sekali saat berinteraksi dengan bot. Jika berhasil dilakukan maka pengguna akan tersimpan dalam basis data.

Setelah melakukan registrasi, bot telegram dapat digunakan untuk permintaan data sesuai dengan kebutuhan dari pengguna data. Ketika pengguna menyampaikan informasi melaui teks dalam bot telegram, maka secara otomatis bot akan memberikan respon berupa informasi yang diminta. Setiap permintaan data yang dilakukan oleh pengguna aplikasi akan dijawab secra otomatis melalui bot telegram. Berikut ini contoh interikasi penggunaan bot telegram dalam permintaan data. 


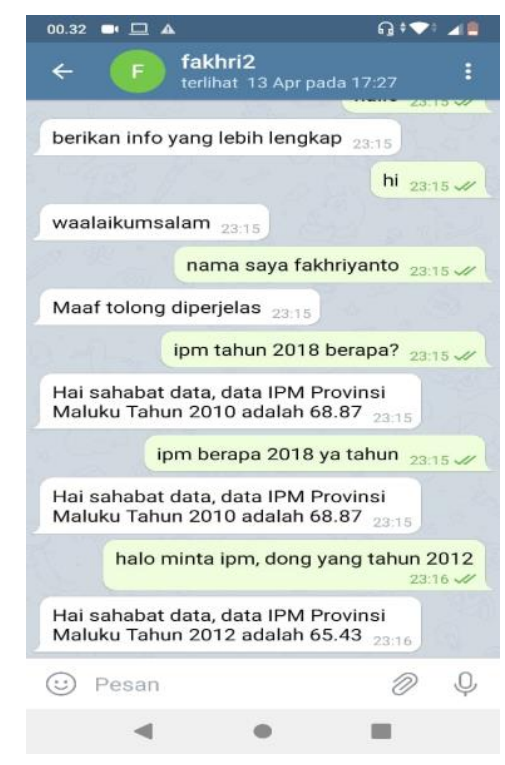

Gambar 9. Contoh Interaksi permintaan data melalui bot telegram

Adapun keuntungan yang diperoleh melalui penggunaan aplikasi bot telegram antara lain: Lebih interaktif, pertanyaan yang diajukan oleh pengguna lebih terfokus sehingga lebih mudah dalam menemukan informasi yang dibutuhkan, pengguna tidak membutuhkan waktu yang lama, karena sistem akan melakukan pencarian dan menjawab lebih cepat sesuai dengan kebutuhan pengguna, memudahan dalam melakukan pencarian, tanpa harus berkunjung secara manual ke BPS Provinsi atau melalui aplikasi web, serta data yang dibutuhkan cepat dan tepat sesuai dengan kebutuhan pengguna data.

\subsection{Pengujian}

Hasil pengujian blackbox terhadap menu yang sudah dilakukan pada sistem bot.

Tabel 2. Hasil pengujian dengan blackbox testing

\begin{tabular}{|c|c|c|c|}
\hline Menu & Skenario & Harapan & Hasil \\
\hline $\begin{array}{l}\text { Registrasi } \\
\text { Pengguna }\end{array}$ & $\begin{array}{l}\text { Masukan } \\
\text { nama } \\
\text { pengguna,a } \\
\text { sal Instansi } \\
\text { dan Tujuan }\end{array}$ & $\begin{array}{l}\text { Nama } \\
\text { pengguna,a } \\
\text { sal Instansi } \\
\text { dan Tujuan } \\
\text { permintaan } \\
\text { data dapat }\end{array}$ & Valid \\
\hline
\end{tabular}

\begin{tabular}{|l|l|l|l|}
\hline & $\begin{array}{l}\text { permintaan } \\
\text { data }\end{array}$ & $\begin{array}{l}\text { disimpan } \\
\text { ke dalam } \\
\text { basis data }\end{array}$ & \\
\hline $\begin{array}{l}\text { Buat } \\
\text { perminta } \\
\text { an data }\end{array}$ & $\begin{array}{l}\text { Penggunam } \\
\text { engakses } \\
\text { jenis } \\
\text { permintaan } \\
\text { data sesuai } \\
\text { dengan } \\
\text { jenis } \\
\text { kebutuhan } \\
\text { data yang } \\
\text { pang }\end{array}$ & $\begin{array}{l}\text { Batajian dan } \\
\text { informasi } \\
\text { mengenai } \\
\text { data yang } \\
\text { dibutuhkan } \\
\text { oleh } \\
\text { pengguna } \\
\text { data }\end{array}$ & Valid \\
diperlukan, & & \\
\hline
\end{tabular}

\section{KESIMPULAN DAN SARAN}

Proses pelayanan data dapat berjalan dengan lebih baik dan cepat jika ditunjang dengan penerapan sistem teknologi Informasi yang mendukung. Penggunaan both telegram sebagai bentuk variasi dalam penyediaan layanan bagi pengguna memberikan kemudahan dan optimalisasi terhadap pengguna data karena peran manusia dalam proses transaksi penyedia data, dapat digantikan melalui telegram. Aplikasi ini telah dijalankan dengan baik dan dapat proses tanya jawab secara manual yang dilakukan beralih ke sistem informasi melaui chatbot dimana sangat membantu pengguna data dalam memberikan informasi dengan mudah, lebih cepat dan tepat.

Penggunaan bot telegram dalam penyediaan data sudah dijadikan sebagai alternatif, namun terdapat bagian yang belum dioptimalkan, Salah satu bagian yang perlu dioptimalkan yaitu dalam rancangan data knowledge yang diisi secara manual dan diharapkan penelitian selanjutnya dapat dibuat rancangan secara otomatis. 


\section{DAFTAR PUSTAKA}

[1] R. Komalasari, "Manfaat Teknologi Informasi Dan Komunikasi Di Masa Pandemi Covid 19," Tematik, vol. 7, no. 1, pp. 38-50, 2020, doi: 10.38204/tematik.v7i1.369.

[2] Medina Azizah, "Jurusan Ilmu Komunikasi Fakultas IImu Sosial dan IImu Politik Universitas Muhammadiyah Malang," Sosiol. Nusant., vol. 6, No 1, pp. 45-54, 2020, doi: /doi.org/10.33369/jsn.5.1.4554.

[3] M. S. Asyaky, "Analisis dan Perbandingan Bukti Digital Aplikasi Instant Messenger Pada Android," J. Penelit. Tek. Inform., vol. Vol. 3 No, no. 1, pp. 220-231, 2019.

[4] Yuliza, "Jurnal Teknologi Elektro, Universitas Mercu Buana ISSN : 2086 9479 Detektor Keamanan Rumah Melalui Telegram Messeger Yuliza Jurusan Teknik Elektro，Fakultas Teknik ISSN : 2086 9479," J. Teknol. Elektro, Univ. Mercu Buana ISSN 2086-9479 Detektor, vol. 9, no. 1, pp. 27-33, 2018.

[5] A. K. N. Wibowo and Y. I. Kurniawan, "Bot Telegram Sebagai Media Alternatif Akses Informasi Akademik," Komputa J. IIm. Komput. dan Inform., vol. 8, no. 1, pp. 110, 2019, doi: 10.34010/komputa.v8i1.3043.

[6] BPS, "https://www.bps.go.id/menu." .

[7] Ananda Dwi, F. Imamah, Y. M. Andre, and Ardiansyah, "Aplikasi Chatbot (Milki Bot) Yang Terintegrasi Dengan Web CMS Untuk Customer Service Pada UKM MINSU," J. Cendikia, vol. XVI, pp. 100-106, 2018.

[8] T. M. F. dan A. M. Taufiai, Membangun Mesin Percakapan Pintar dengan Python dan Telegram Both. Yogyakarta:

Deepublish, 2021.

[9] J. Junaedy and A. Munir, "Rancang Bangun Sistem Pengelolaan Data Kuliah Kerja Lapang Plus Memanfaatkan Framework Codeigniter Dengan Menggunakan Metode Waterfall," IIk. J. IIm., vol. 9, no. 2, pp. 203-210, 2017, doi: 10.33096/ilkom.v9i2.141.203-210.

[10] L. Pichponreay, J. H. Kim, C. H. Choi, K. H. Lee, and W. S. Cho, "Smart answering Chatbot based on OCR and Overgenerating Transformations and Ranking," Int. Conf. Ubiquitous Futur. Networks, ICUFN, vol. 2016-Augus, pp. 1002-1005, 2016, doi: 10.1109/ICUFN.2016.7536948.

[11] E. Yuniar and H. Purnomo, "Implementasi Chatbot 'Alitta' Asisten Virtual Dari Balittas Sebagai Pusat Informasi Di Balittas," Antivirus J. Ilm. Tek. Inform., vol. 12, no. 1, pp. 24-35, 2019.

[12] T. M. A. M. Taufiai, Membangun Mesin Percakapan Pintar dengan Pyhton dan Telegram Both. 2021.

[13] H. Kurniawan, B. Setiyono, and R. R. Isnanto, "Aplikasi Penjawab Pesan Singkat Automatis Dengan Bahasa Python," Tugas Akhir, 2011.

[14] F. Firdausillah and Arieansyah, "Implementasi Algoritma Levenshtein Distance Sebagai Chatbot Agen Pariwisata Berbasis Aplikasi LINE," Semin. Nas. APTIKOM, no. 1, pp. 377-385, 2019. 